\title{
Seven Level Inverter Fault Mitigation Using Redundant Cell for Induction Motor Drive
}

\author{
B. Madhu Kiran ${ }^{1}$, B. V. Sanker Ram ${ }^{2}$ \\ ${ }^{1}$ Department of Electrical and Electronics Engineering, Potti Sriramulu Chalavadi Mallikarjuna Rao College of \\ Engineering and Technology, Vijayawada, India \\ ${ }^{2}$ Department of Electrical \& Electronics Engineering, JNTUH College of Engineering, Hyderabad, India
}

\begin{tabular}{l} 
Article Info \\
\hline Article history: \\
Received Jun 12, 2018 \\
Revised Aug 16, 2018 \\
Accepted Aug 31, 2018 \\
\hline Keywords: \\
Fault \\
Fault detection \\
Inverter \\
Mitigation \\
Redundant cell \\
\hline
\end{tabular}

\begin{abstract}
Faults that might occur in inverter driven induction motor drives. In this paper, seven-level multi level inverter was taken up for testing of mitigation using redundant cell and the results were compared with five-level inverter to exhibit the performance of mitigation policy. This paper presents analysis of inverter feeding an induction motor drive when switch open and short fault occurs. When the fault occurs, the redundant cell activates and thus the drive system operates. In this paper, the function for redundant cell was explained with the results of drive system simulated in Matlab/Simulink.
\end{abstract}

Copyright $(0) 2018$ Institute of Advanced Engineering and Science. All rights reserved.

\section{Corresponding Author:}

Madhu Kiran,

Departement of Electrical and Electronics Engineering,

Potti Sriramulu Chalavadi Mallikarjuna Rao College of Engineering and Technology,

Krishna District, Vijayawada, AP, India.

Email: madhukiran1.eee@gmail.com

\section{INTRODUCTION}

AC induction machines, especially polyphase induction machines presently are widely used in a large variety of industrial installations and applications. The design of these ac induction machines has been revisited and revised over many years since their discovery and the discovery of the magnetic rotating field phenomena by Nikola Tesla in the 1880's, and its application to rotating machinery. In the last century, induction machines have been very well developed and applied to the industrial field by the engineers and researchers. One well-known kind of induction machine is the so-called squirrel-cage (rotor) induction machine, and this kind of rotor structure really enhances the reliability and ruggedness of this type of machine, as well as significantly decreases the cost of its operation and maintenance [1-3]. Thus, these modern squirrel-cage induction machines possess a ruggedness and relative simplicity of design, which results in reduced manufacturing and maintenance costs. Accordingly, these squirrel-cage induction machines are now widely utilized and are now the most common type of induction machines utilized in industry today.

In addition, due to the development in power semiconductor technology in the last few decades and the associated technology of electronic power processing (changing ac voltage, current, and frequency at will), induction machines are being utilized in those adjustable speed drive (ASD) applications, in which one needs complicated and precise control of speed and torque. Moreover, the continued to breakthroughs in the digital electronics field provided significant help in the ac motor-drive area. For example, modern digital processing units with high speed processing capabilities are able to host and execute real-time complex control algorithms for variable/adjustable speed drives (VSDs/ASDs). Modern induction machines and their 
drive control systems possess relatively high degree of reliability nowadays. However, being practical devices with parts and components they are still prone to failures. These failures may happen in the machines themselves, such as bearing faults, stator faults, and rotor faults. These short-circuit faults include inter-turn short-circuit faults, open-coil faults, phase-to-phase short-circuit faults, or phase-to-ground faults. Rotor broken-bar and end ring faults have been also reported in the above survey carried out by EPRI, and were reported to constitute about $9 \%$ of motor faults. Broken-bar faults are mainly due to thermal and mechanical stresses especially due to frequent starting operations, aging effects and/or manufacturing defects. On the other hand, various types of severe faults may also happen in the power-electronics portion (drive) components of motor-drive systems [4-6].

The main function of ac motor-drive systems [7-9] is controlling motor terminal currents and voltages in order to achieve reliable control of torque and speed under stable operating conditions. Such torque and speed may be manually selected by the user, or by an automated system in case of automated industrial processes. Such faults in the power electronic portion of motor-drive system may happen in the rectifier bridge, cables, or in the power fuse connecting the inverter bridge to the rectifier. These faults could constitute catastrophic failure in such motor-drive systems. Nowadays, the widespread use of ac induction motor-drive systems in critical applications require industry to develop and manufacture more intelligent systems with enhanced reliability and survivability, in order to utilize them under severe environmental and other severe operating conditions, such as for example underground mines, deep oil wells, and deep-sea exploration. Therefore, it is significant to develop rigorous fault mitigation techniques in such ASDs and fault tolerant ASD systems for such types of industrial motor-drive applications [10-11] and thus raises the need for development of reasonably accurate modeling and simulation techniques for such ASD motor-drive systems under healthy and faulty operating conditions. This paper discusses the short and open fault mitigation with redundant cell simulated for five-level MLI, seven-level MLI.

\section{MULTILEVEL INVERTER FOR ELECTRIC VEHICLE}

Cascaded h-Bridge five-level inverter driving induction motor was shown in Figure 1. In electric vehicle application, batteries are often used to properly manage the power. Usually supply power from DC sources is fed to induction motor drive through multi-level inverter in normal mode of operation. If regenerative braking is employed in the circuit, power from load to source transfers in charging mode of operation.

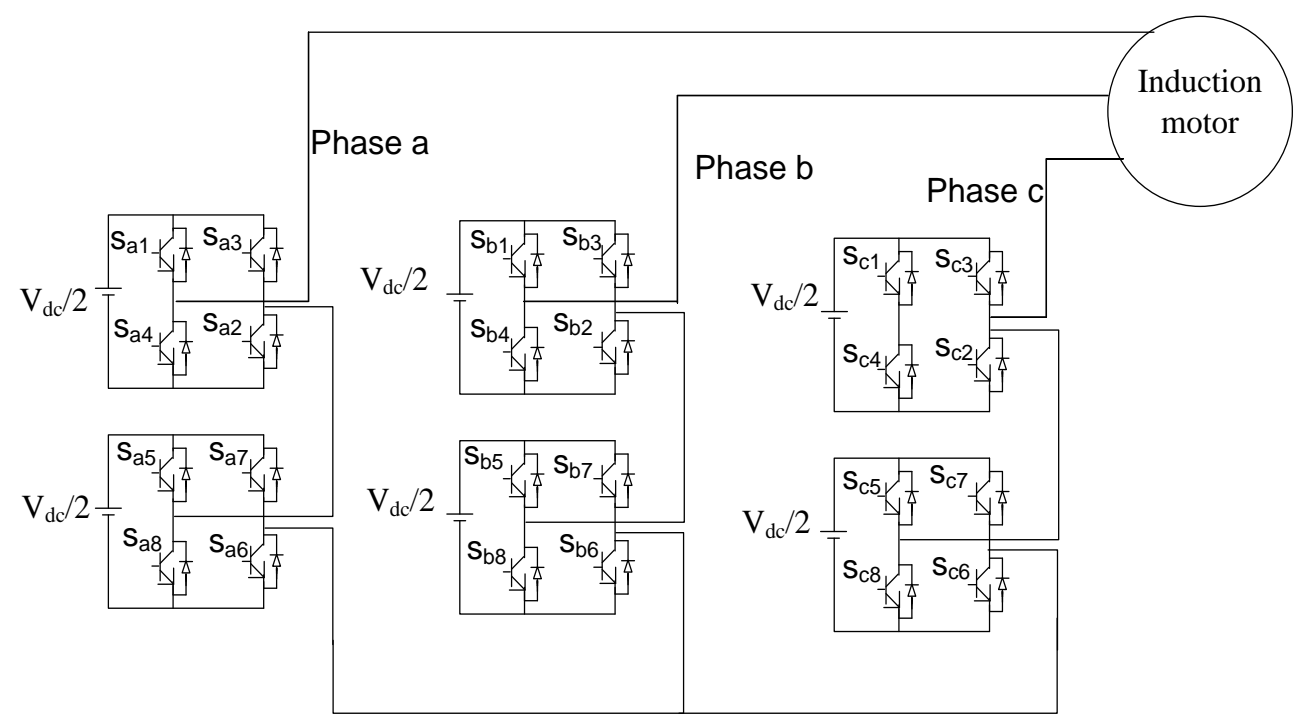

Figure 1. Cascaded H-bridge five level inverter based induction motor

Multi-level topology of inverters comprises of static switches with number of DC sources. The output of multi-level inverter is in form of stepped wave having step levels depending on level of MLI. High voltage output can be obtained from MLI with different levels in voltage waveform thus obtaining high power that can be utilized for electric vehicle applications or for hybrid electric vehicle drive system. 
The number of voltage levels decides the output voltage and the increase in levels of output reduces the total harmonic distortion in the output waveform. High the levels in output low the harmonic distortion in output waveform. Structure of multi-level inverter is furnished such that voltage sharing issues does not arise.

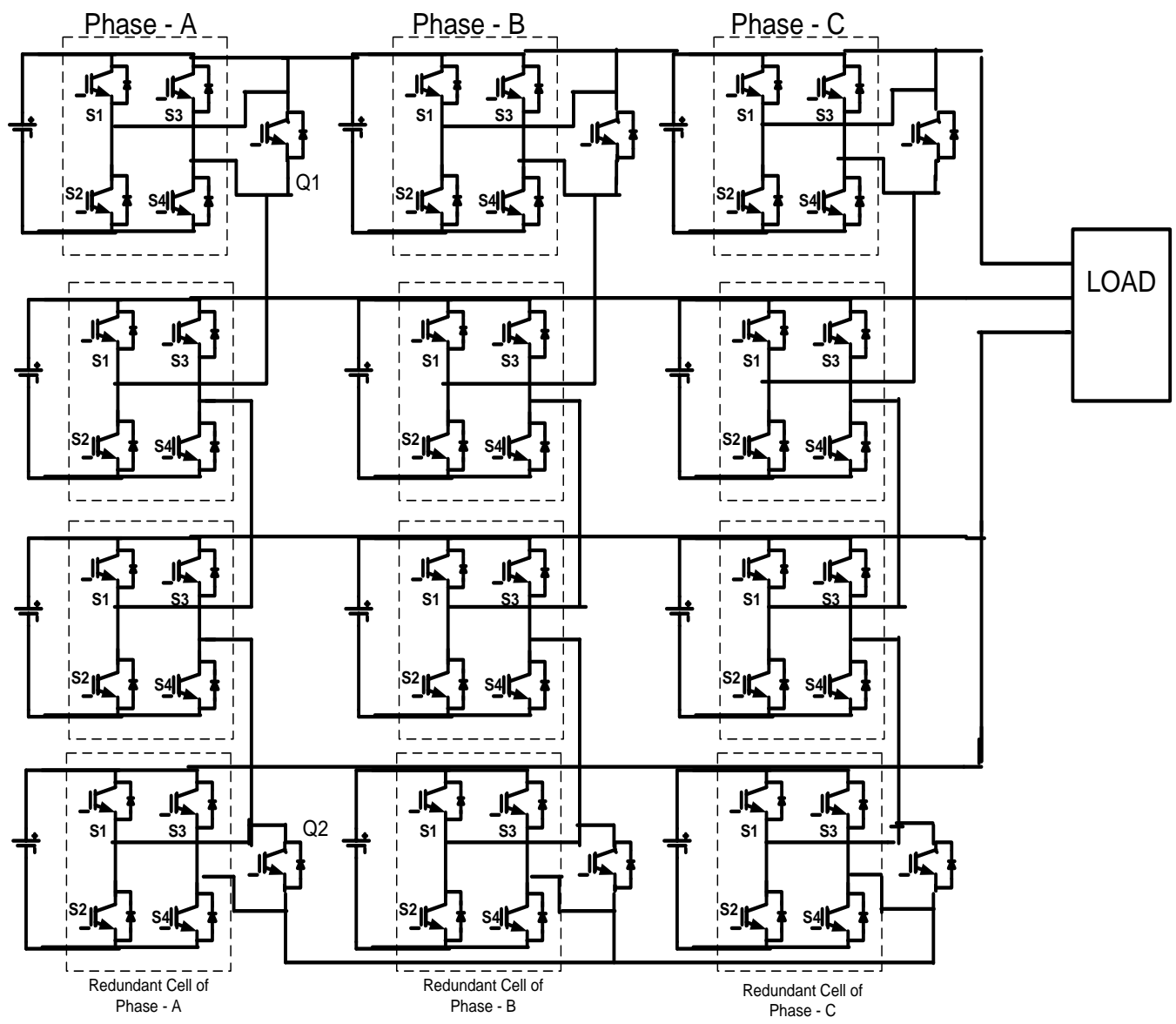

Figure 2. Seven-level MLI with redundant cell

\section{FAULT ANALYSIS}

Most of the faults that occur in drive system are of failure in semiconductor switches used in inverter circuits. Commonly used switching device in inverter circuits are IGBT, because of their capability of handling high voltage and current rating and also can withstand short circuit currents for a short period of time. But IGBT suffers from drawback of high thermal stress. Failure in switching device can be termed due to failure due to opening of diode, diode short, and gate open and short fault.

Out of six faults, major faults that occur are

a. IGBT open-circuit fault.

b. IGBT short-circuit fault. the next section.

Redundant cell logic was applied for the two type of faults and mitigation process was explained in

\section{REDUNDANT CELL WITH LOGIC}

Redundant cell is an extra bridge circuit added to the inverter circuit. This redundant cell acts and deactivates during fault and when no fault condition. Figure 2 shows the nine-level MLI with redundant cell for fault mitigation. During fault condition, the switch Q1 in the upper part of the phase will be ON and viceversa. The lower switch Q2 will be ON when no fault and will be OFF during faulty conditions. Fault is equal to zero when open circuit fault condition and the fault is equal to 1 when short fault occurs in phase of the inverter. 


\section{RESULTS AND ANALYSIS}

For the mitigation, the fault was created at 0.4 seconds and made to persists upto 0.6 seconds. At 0.6 sec the fault mitigation was done. The results were shown accordingly along with respective THDs.

\subsection{Five-level with open fault mitigation}

Figure 3 shows the three phase line voltage feeding induction motor with switch open condition and mitigation. The three-phase distorted wave due to fault in open switch voltages in 5-level inverter with fault mitigation with switch open fault is shown in Figure 4. Harmonic distortion content in 5-level inverter phase voltages with no fault condition is given in Figure 5 while distortion content with fault is given in Figure 6. Figure 7 shows fault mitigated distortion content in phase voltage.

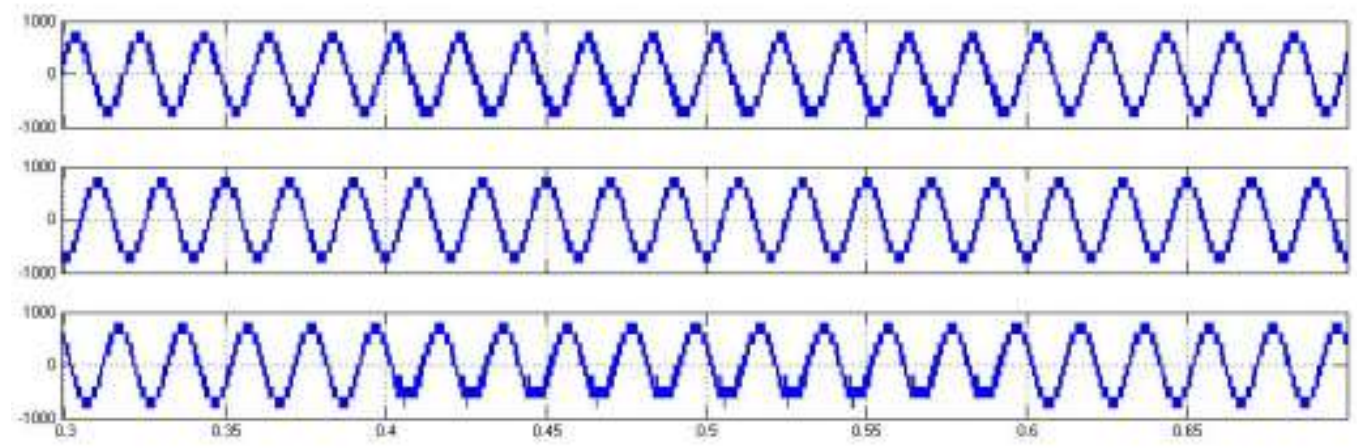

Figure 3. Three phase line voltage with switch open fault mitigation
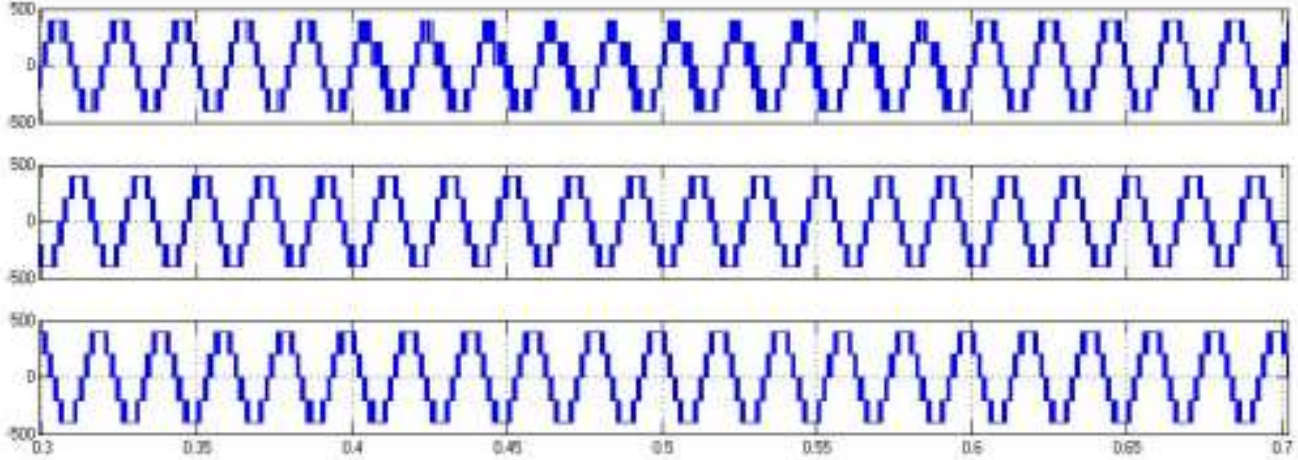

Figure 4. Three phase voltages with switch open fault mitigation

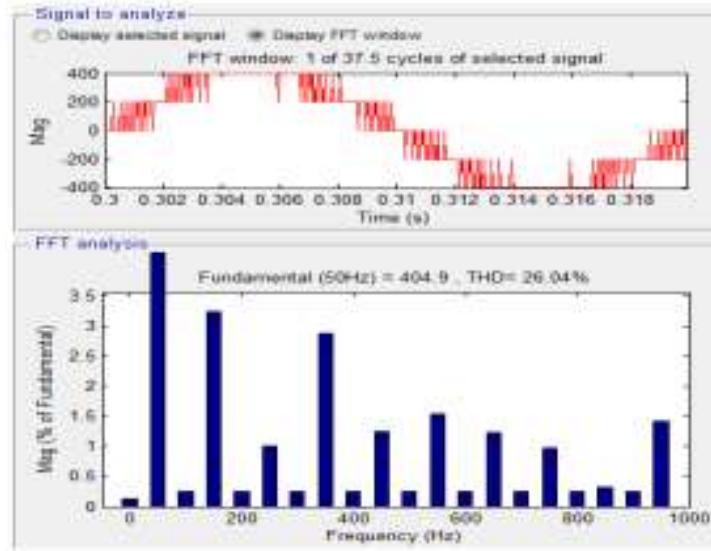

Figure 5. THD in phase voltage with switch open mitigation (before fault)

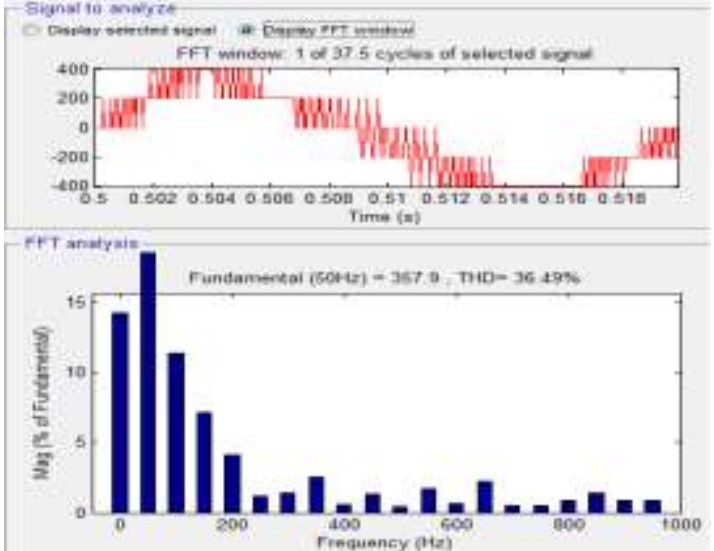

Figure 6. THD in phase voltage with switch open mitigation (during fault) 


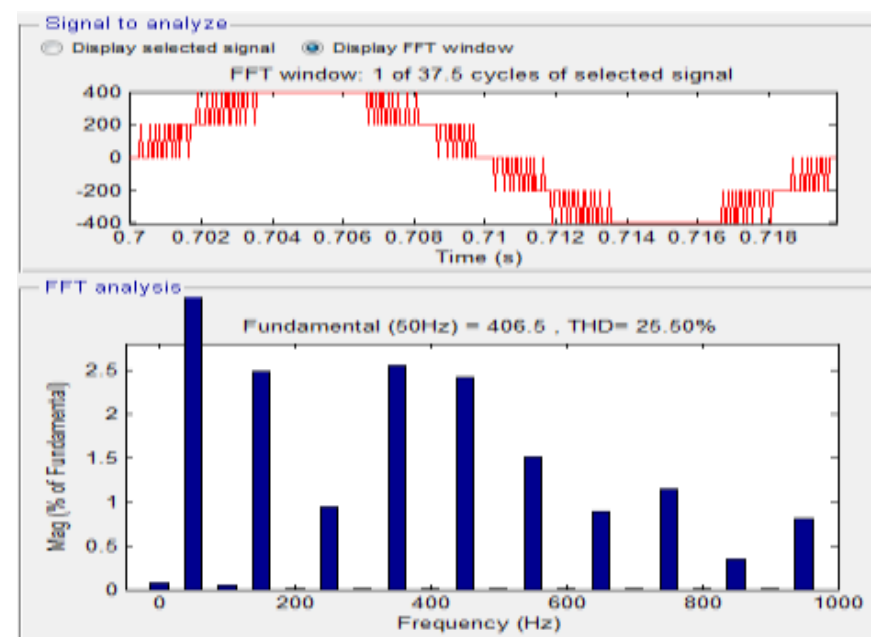

Figure 7. THD in phase voltage with switch open mitigation (after fault mitigation)

Figure 8 shows the line currents and can be observed that due to fault persistence, line currents are distorted and Figure 9 shows the stator currents, speed and torque characteristics of induction motor.

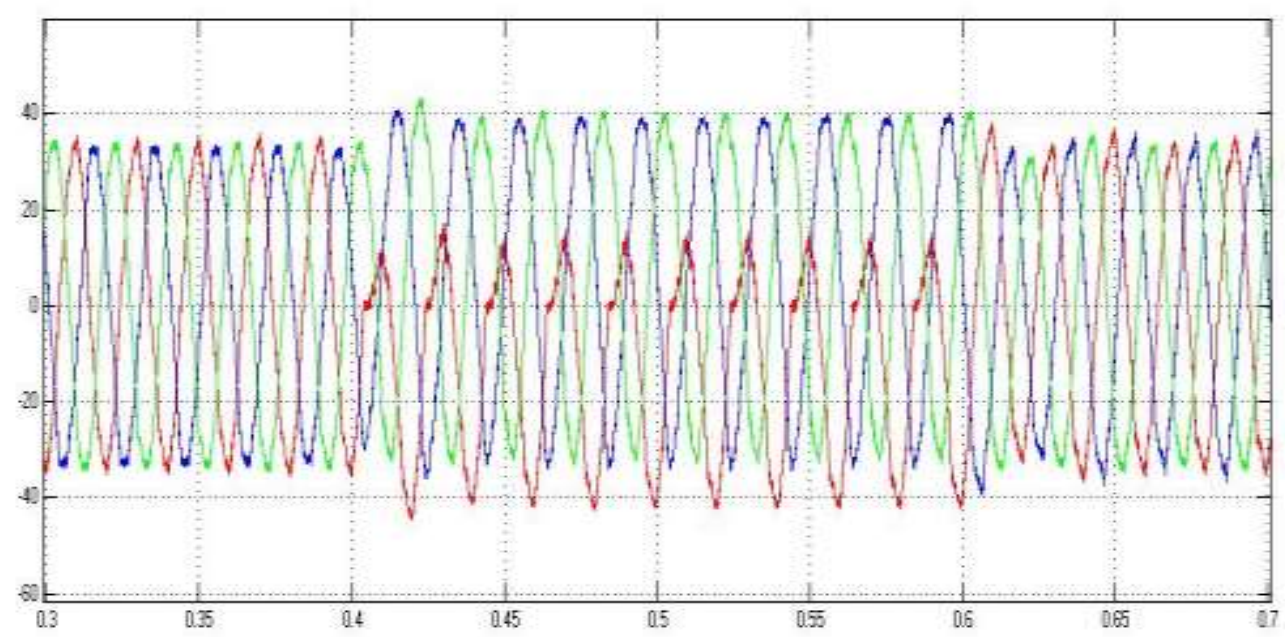

Figure 8. Line current with switch open mitigation
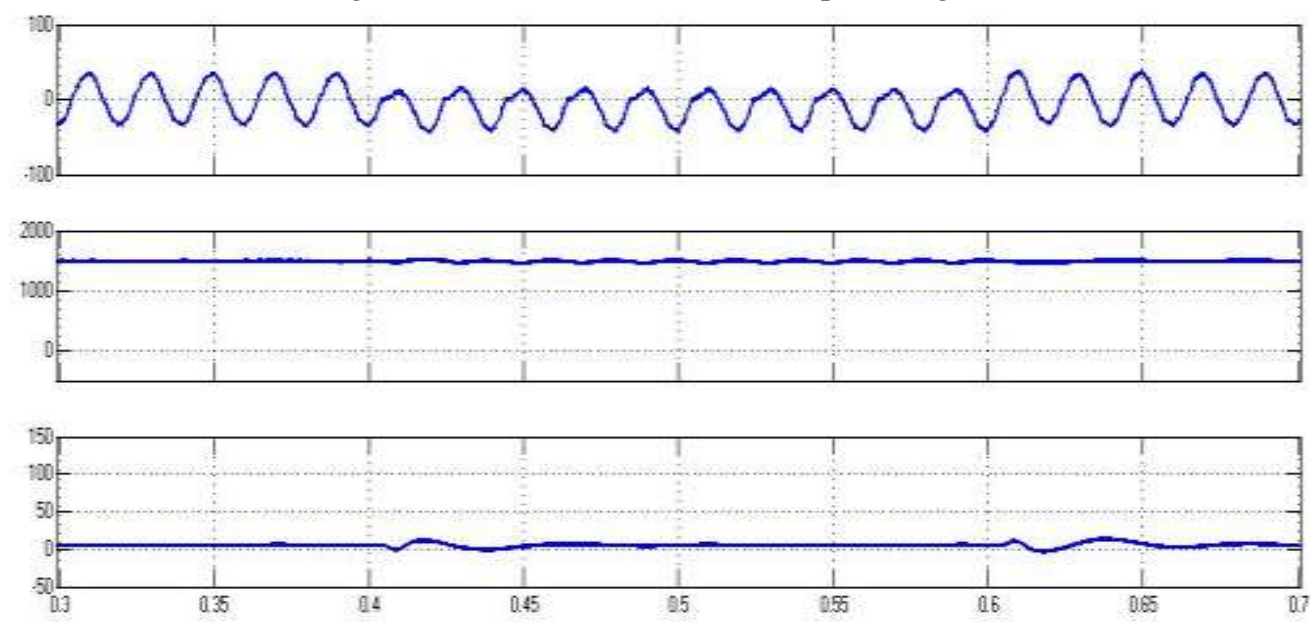

Figure 9. Stator current, speed and torque of induction motor with switch open mitigation 
THD in stator current before fault was shown in Figure 10 while Figure 11 during the fault THD and Figure 12 THD after fault mitigation. During fault total harmonic distortion was high and during normal conditions, harmonic distortion was within limit maintained below $5 \%$.

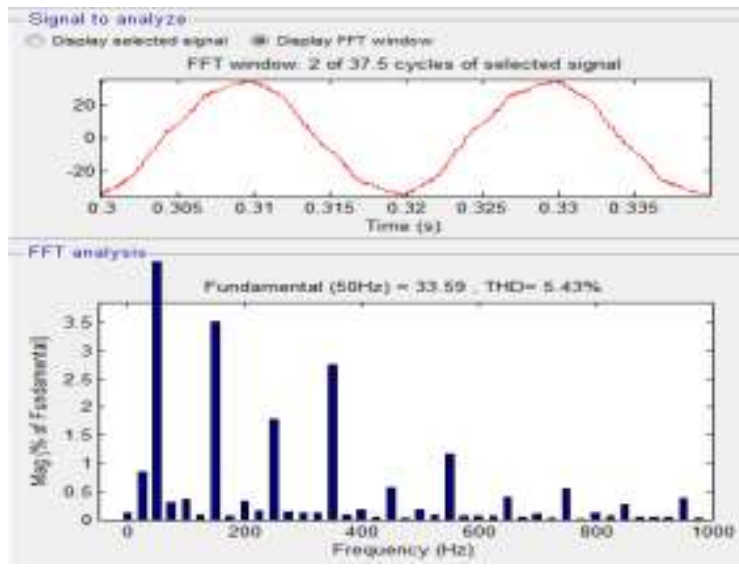

Figure 10. THD in stator current with switch open mitigation (before fault)

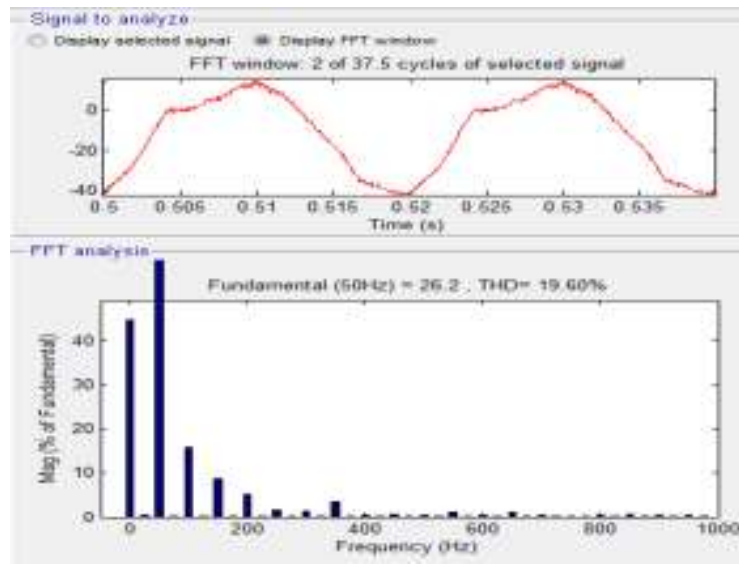

Figure 11. THD in stator current with switch open mitigation (during fault)

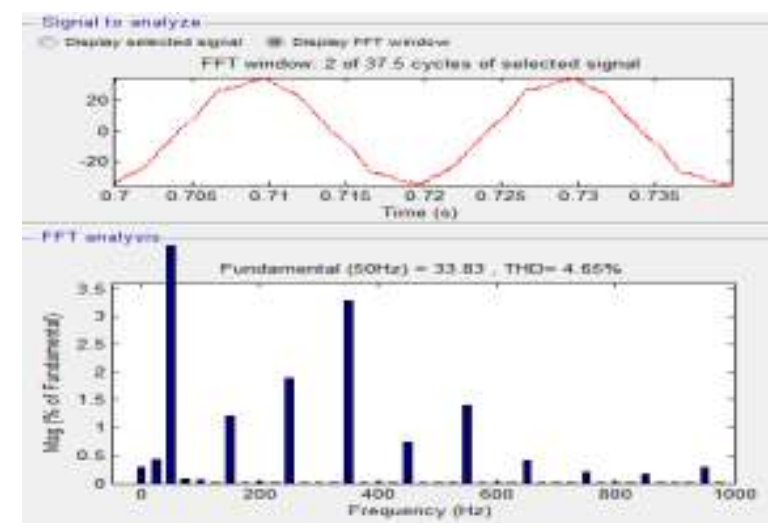

Figure 12. THD in phase voltage with switch open mitigation (after fault mitigation)

\subsection{Five-level with short fault mitigation}

Small distortion is observed in phase voltage and line voltage due to short type of fault in inverter. Figure 13 indicates the line voltages distorted from 0.4 to $0.6 \mathrm{sec}$. The three-phase distorted wave due to fault in open switch voltages in 5-level inverter with fault mitigation with switch open fault is shown in Figure 14.

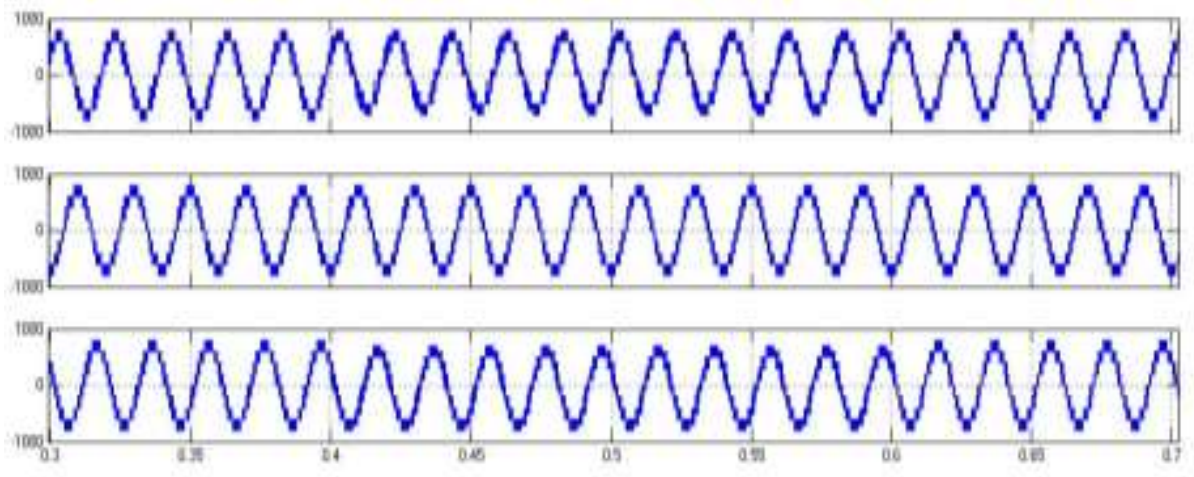

Figure 13. Line voltage with switch short fault mitigation 

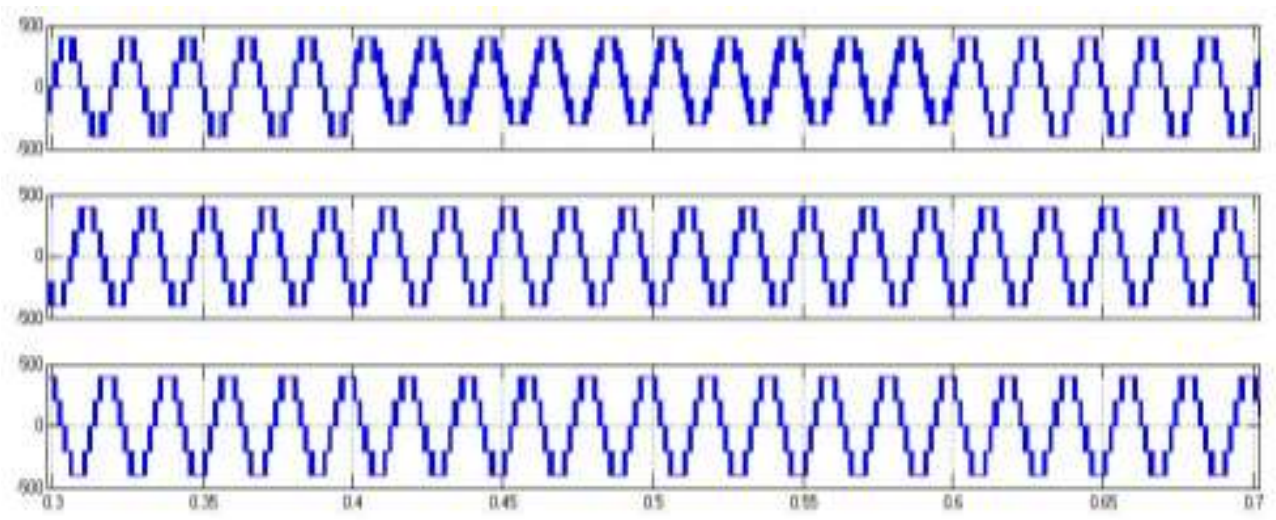

Figure 14. Phase voltage with switch short fault mitigation

Harmonic distortion content in 5-level inverter phase voltages with no fault condition is given in Figure 15 while distortion content with short fault is given in Figure 16. Figure 17 shows fault mitigated distortion content in phase voltage.

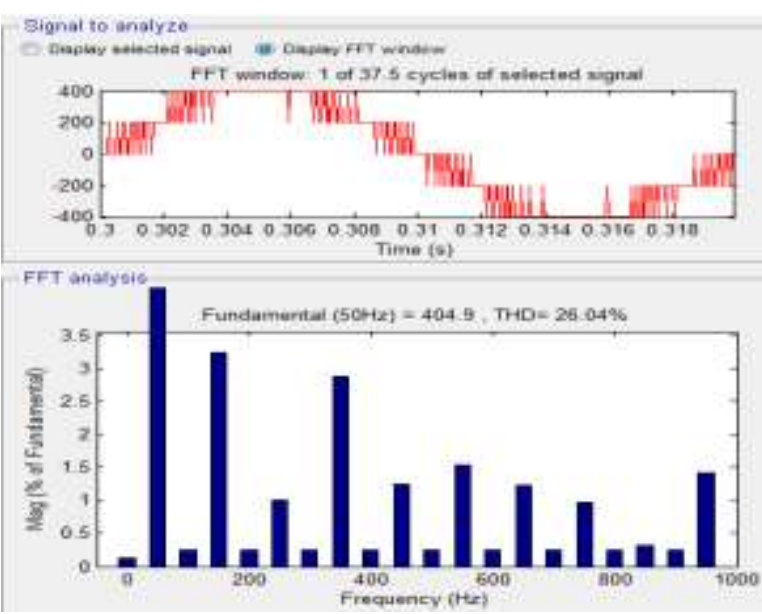

Figure 15. THD in phase voltage with IGBT short mitigation (before fault)

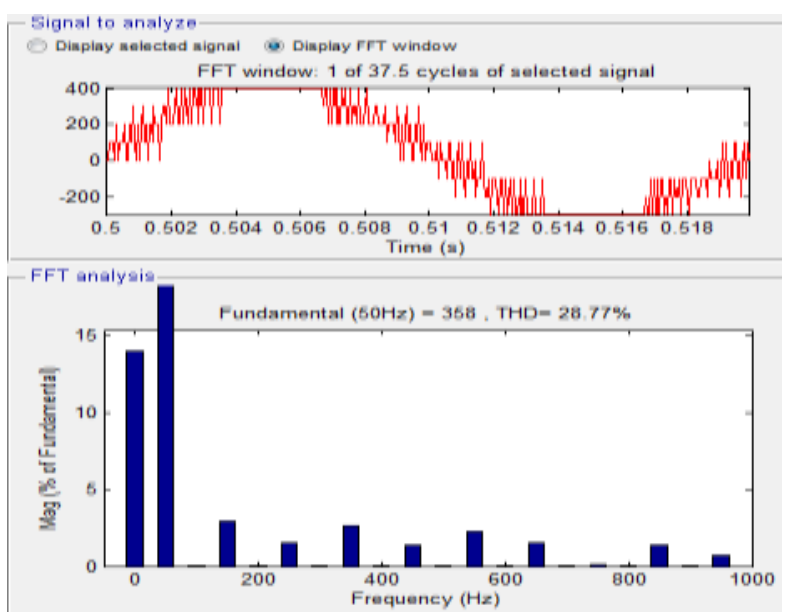

Figure 16. THD in phase voltage with IGBT short mitigation (during fault)

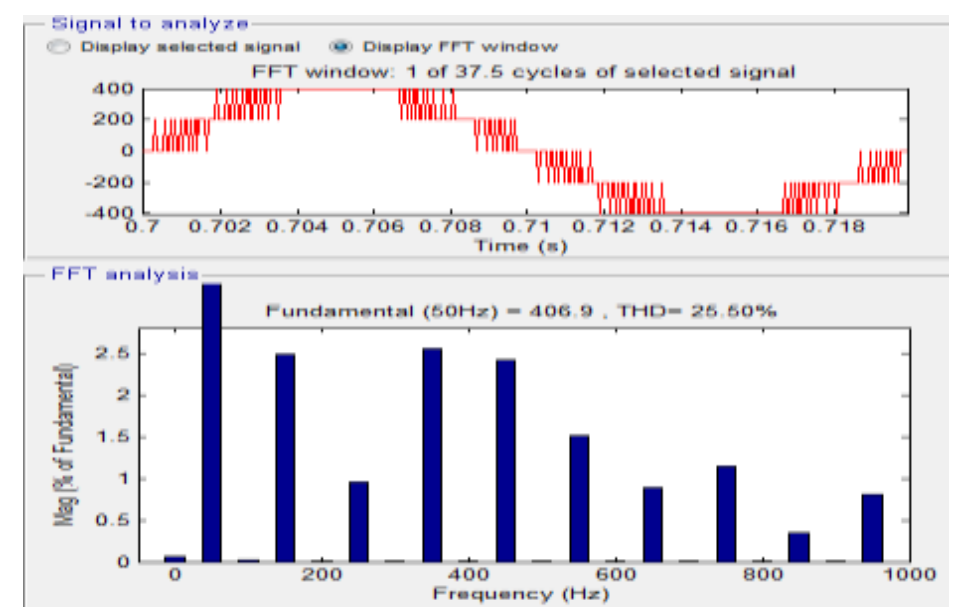

Figure 17. THD in phase voltage with IGBT short mitigation (after fault mitigation) 
Figure 18 indicates the distorted line currents from $0.4 \mathrm{sec}$ to $0.6 \mathrm{sec}$ and Figure 19 shows the stator currents, speed and torque characteristics of induction motor. Speed and torque are just distorted at $0.4 \mathrm{sec}$ and $0.6 \mathrm{sec}$ and otherwise normal.

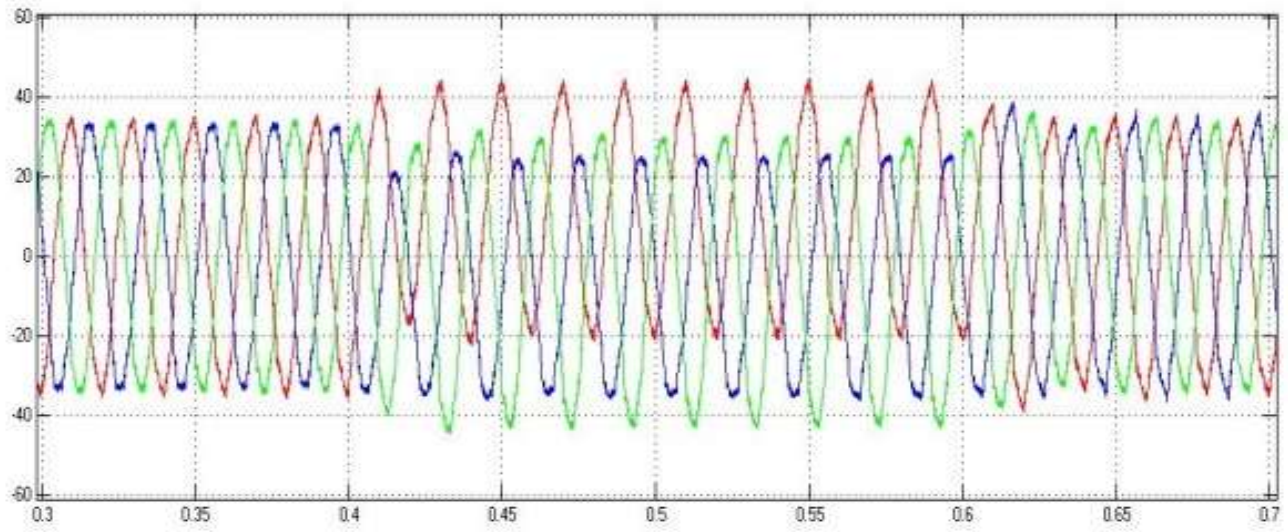

Figure 18. Line current with switch short mitigation
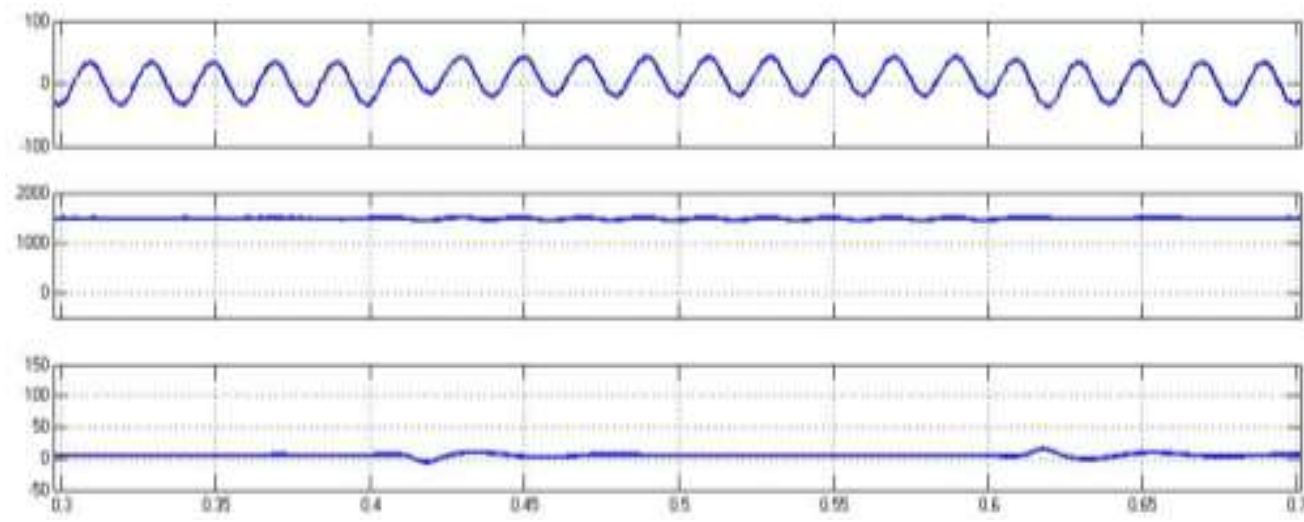

Figure 19. Stator current, speed and torque of induction motor with switch short mitigation

THD in stator current was observed to be $5.43 \%$ before fault was shown in Figure 20 while Gigure 21 during the fault THD is $5.49 \%$ and Figure 22 THD after fault mitigation is $4.64 \%$.

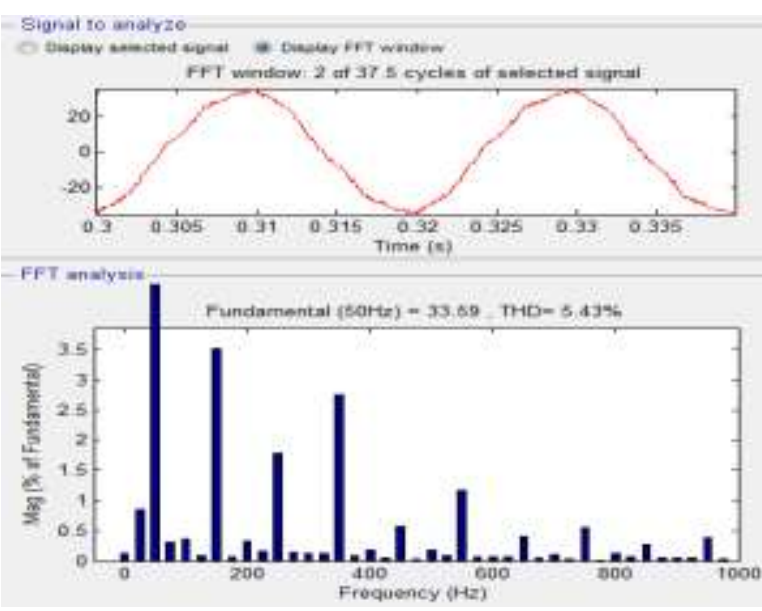

Figure 20. THD in stator current with switch short mitigation (before fault)

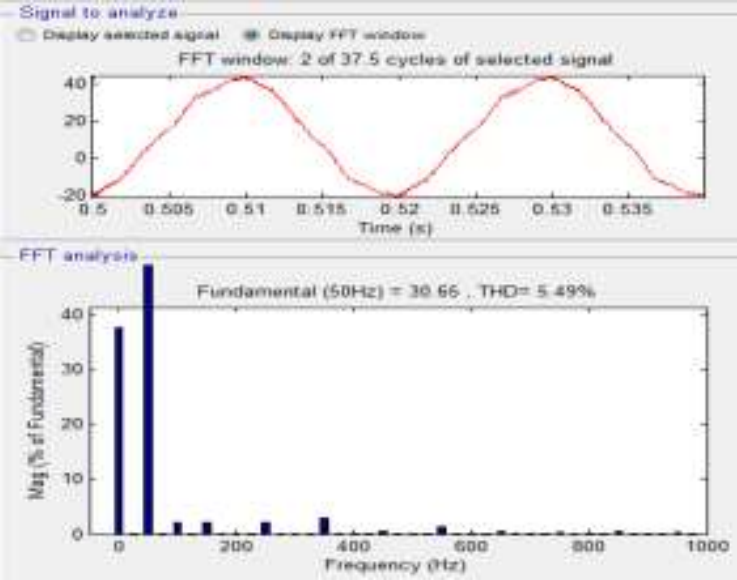

Figure 21. THD in stator current with switch short mitigation (during fault 


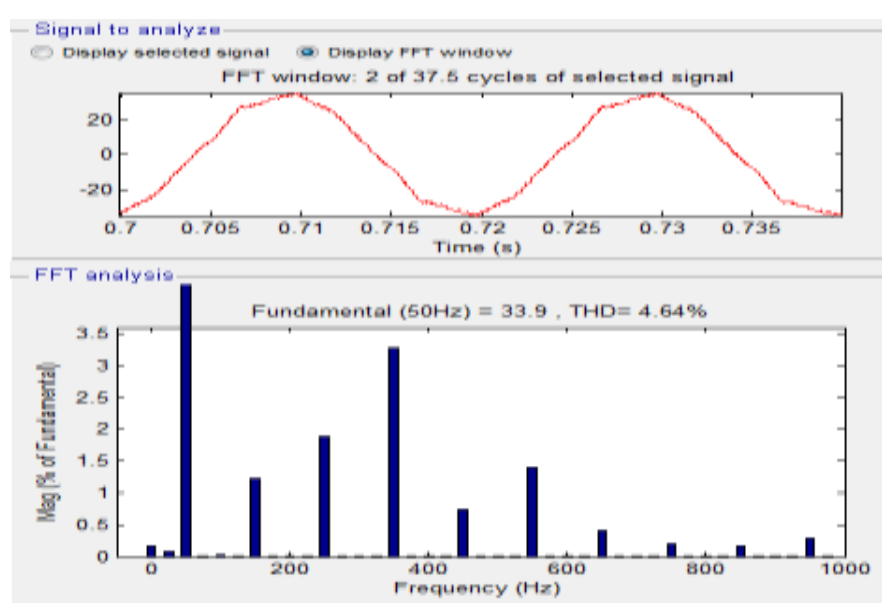

Figure 22. THD in stator current with switch short mitigation (after fault mitigation)

\subsection{Seven-level with open fault mitigation}

The line voltages distorted due to fault pertaining to 7-level inverter and phase voltages are shown in Figure 23 and Figure 24 respectively.

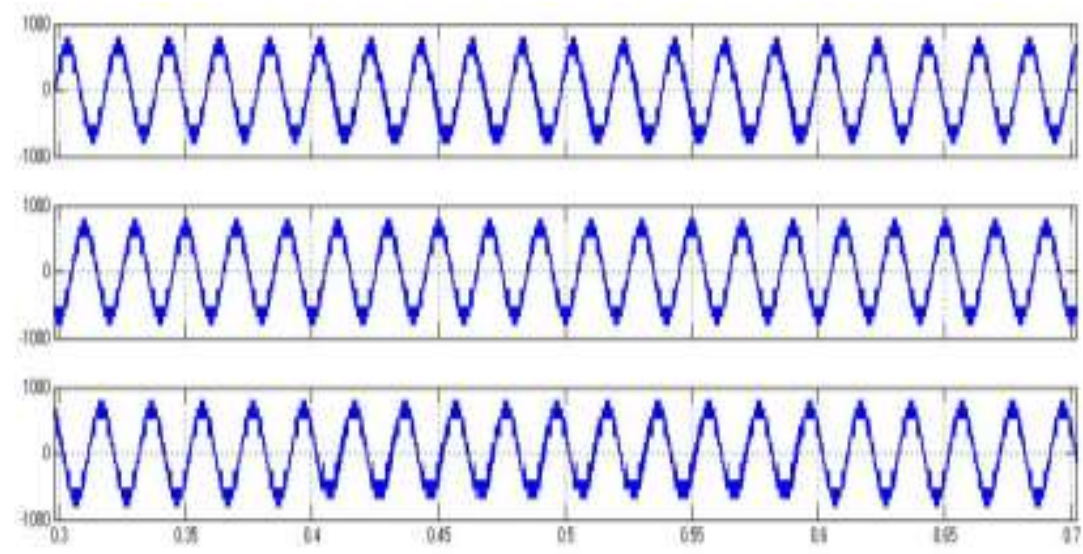

Figure 23. Line voltage with switch open fault mitigation
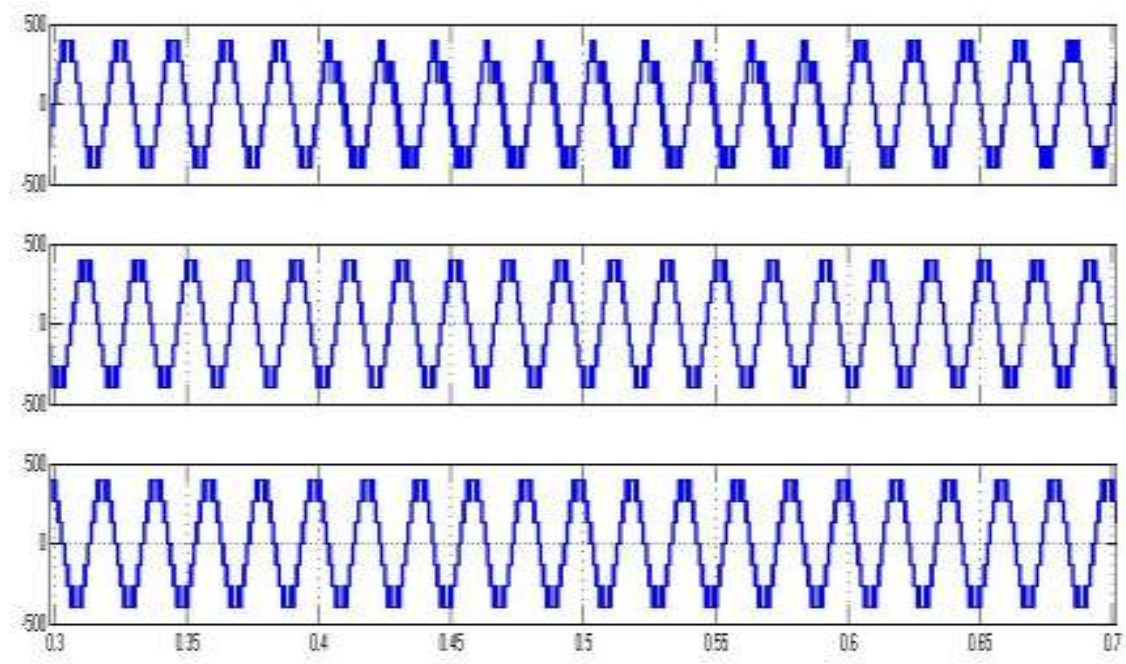

Figure 24. Phase voltage with switch open fault mitigation 
Harmonic distortion content in 7-level inverter phase voltages with no fault condition is given in Figure 25 while distortion content with fault is given in Figure 26. Figure 27 shows fault mitigated distortion content in phase voltage.

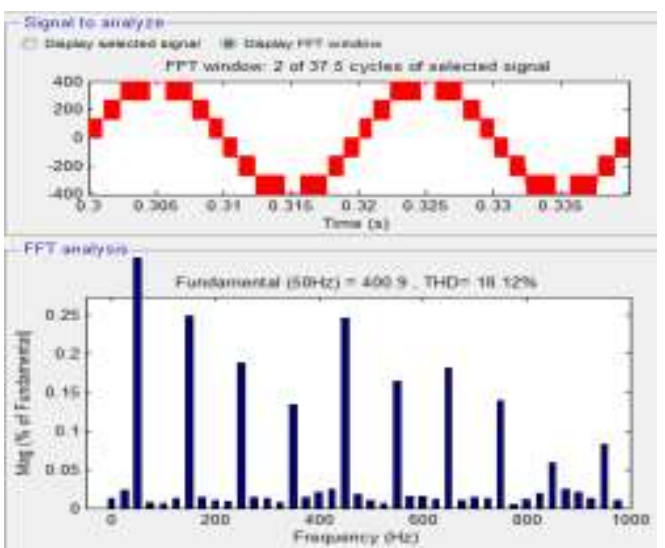

Figure 25. THD in phase voltage with switch open mitigation (before fault)

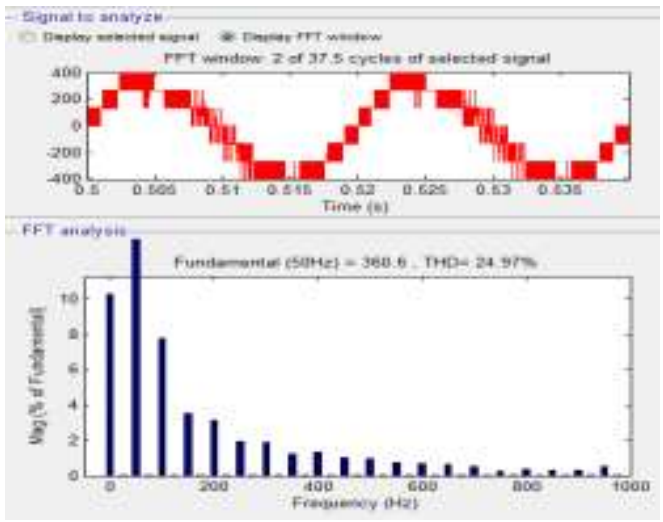

Figure 26. THD in phase voltage with switch open mitigation (during fault)

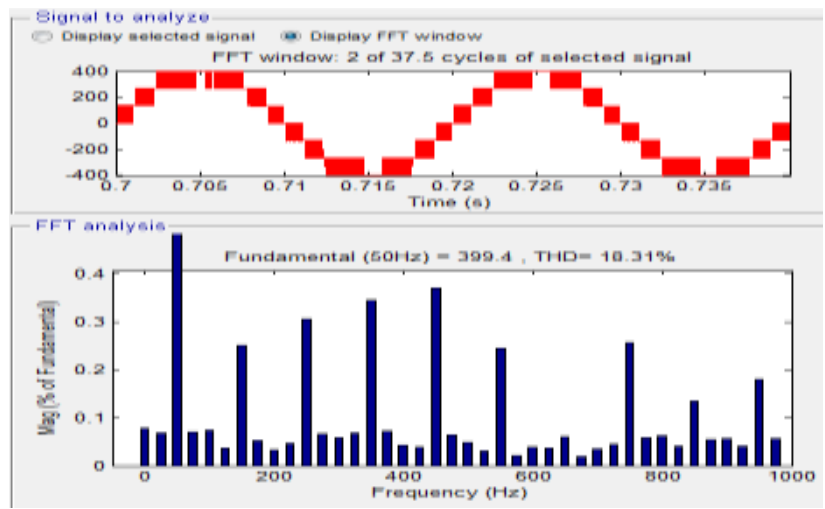

Figure 27. THD in phase voltage with switch open mitigation (after fault mitigation)

Figure 28 shows the line currents and Figure 29 shows the stator currents, speed and torque characteristics of induction motor of 7-level open fault mitigation.

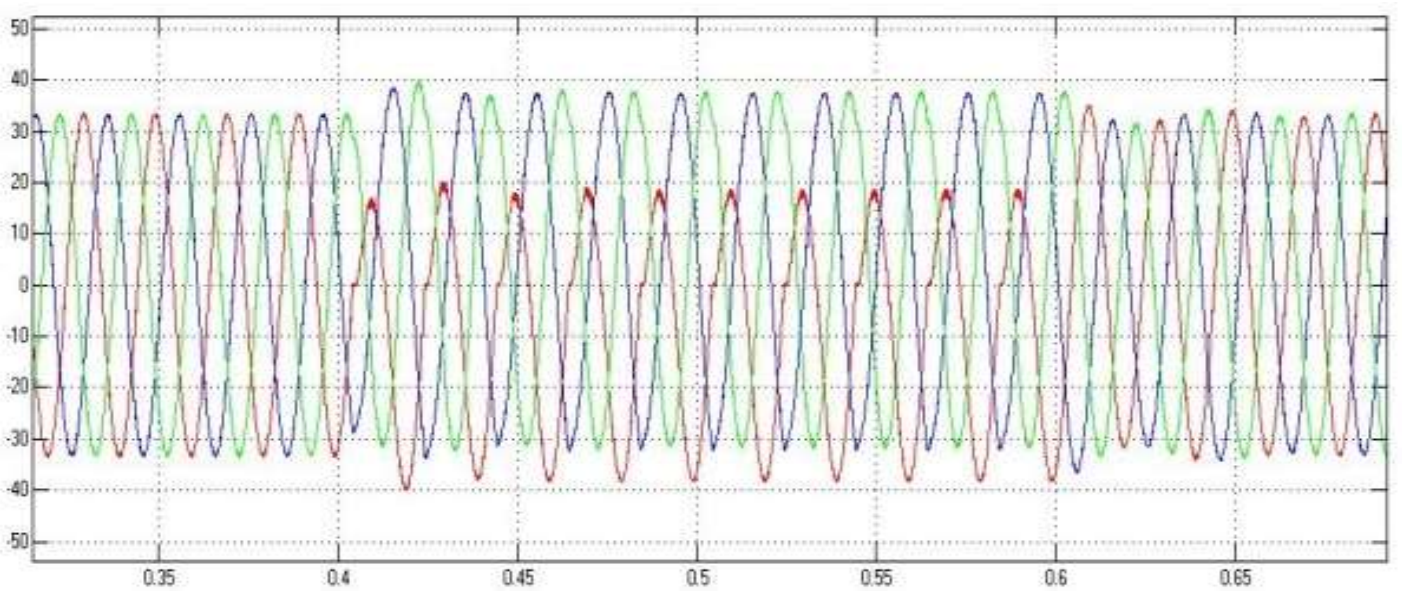

Figure 28. Line current with switch open mitigation 

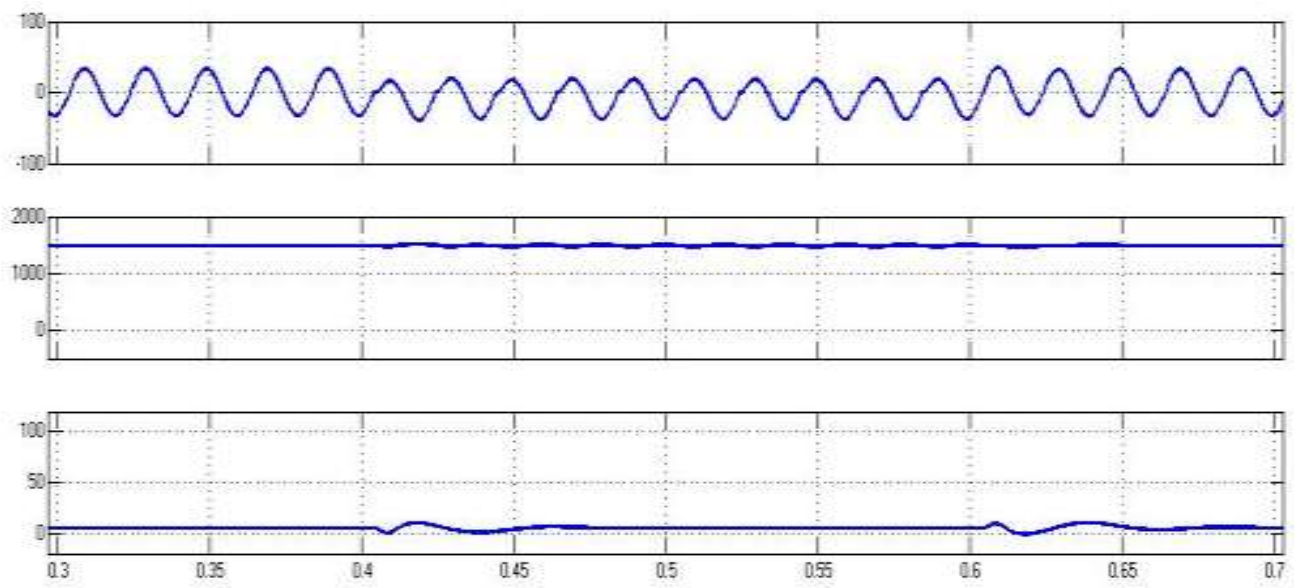

Figure 29. Stator current, speed and torque of induction motor with switch open mitigation

THD in stator current before fault was shown in Figure 30 while Figure 31 during the fault THD and Figure 32 THD after fault mitigation.

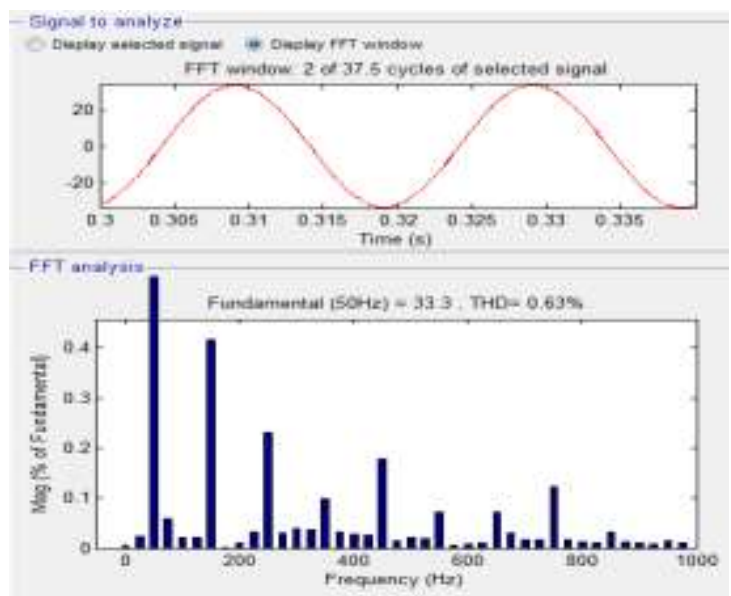

Figure 30.THD in stator currents with switch open mitigation (before fault)

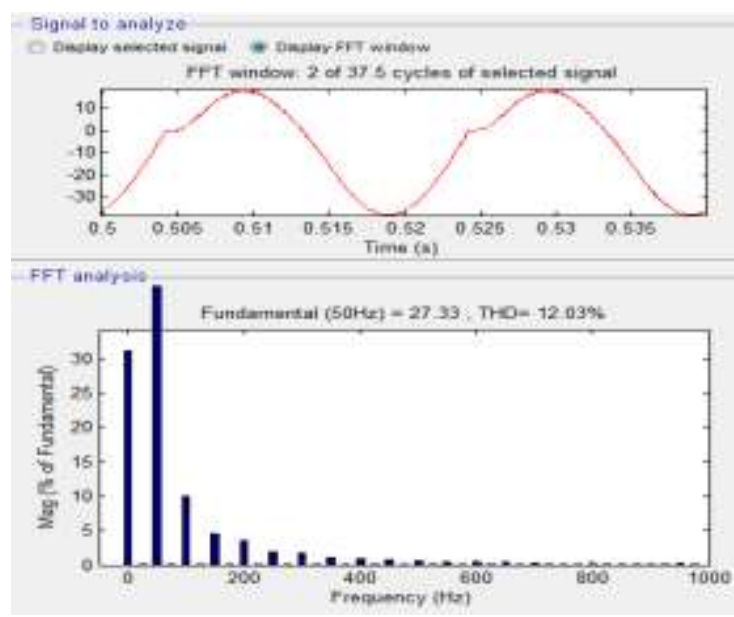

Figure 31.THD in stator current with switch open mitigation (during fault)

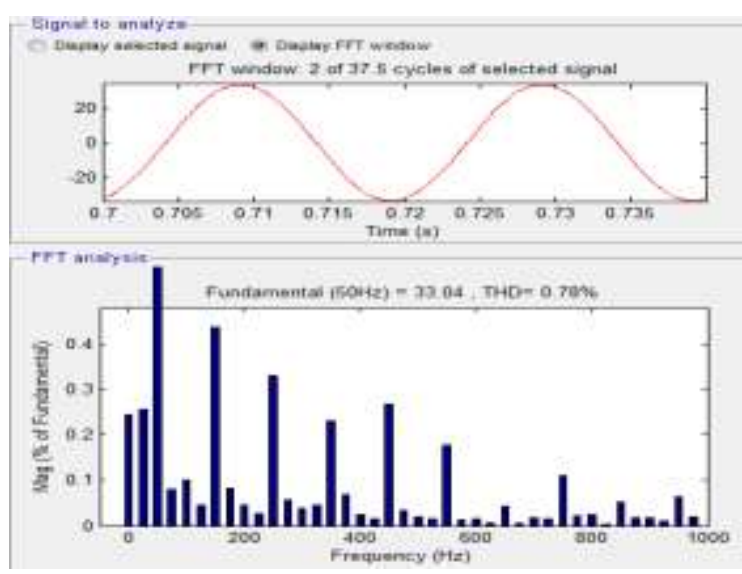

Figure 32.THD in stator current with switch open mitigation (after fault mitigation) 


\subsection{Seven-level short fault mitigation}

The three-phase distorted wave due to fault in short switch voltages in 7-level inverter with fault mitigation with switch short fault is shown in Figure 33 along with line voltages in Figure 34.
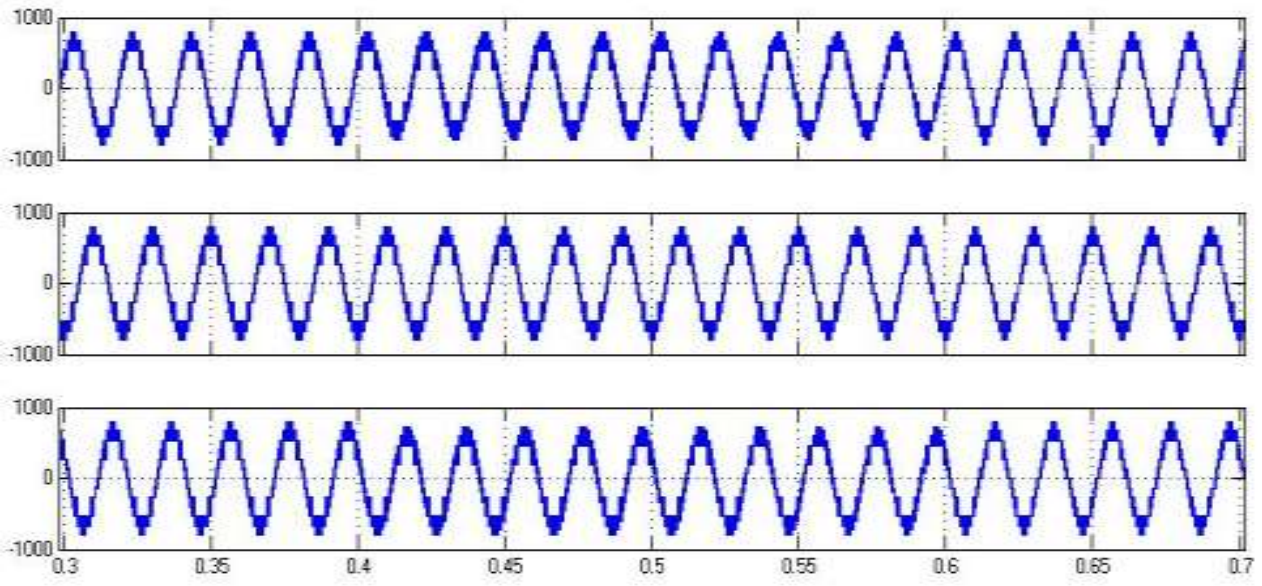

Figure 33. Line voltage with switch short fault mitigation
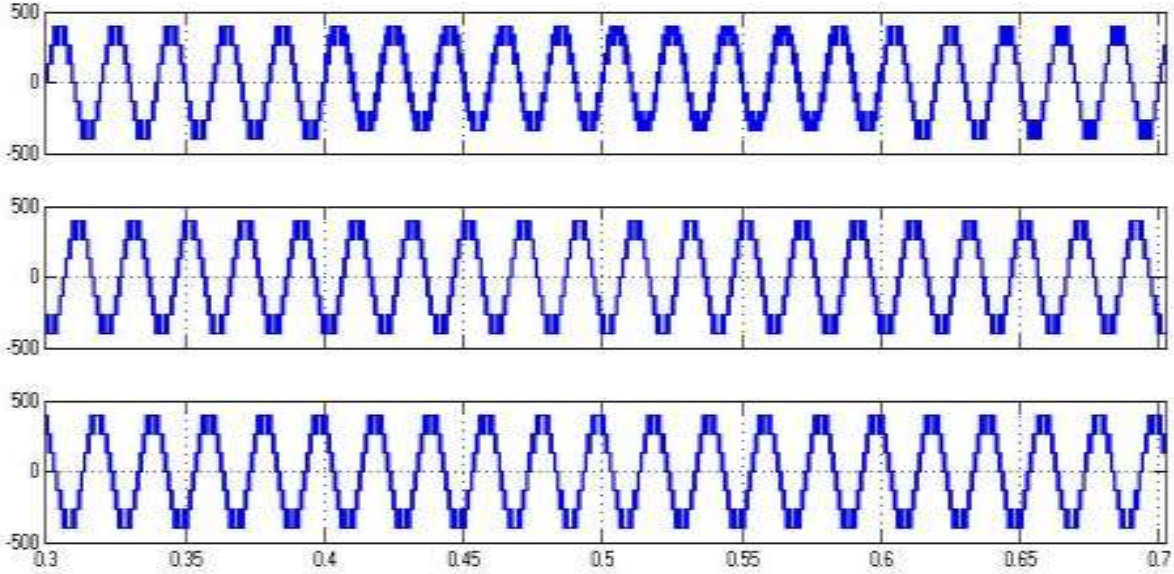

Figure 34. Phase voltage with switch short fault mitigation

Harmonic distortion content in 7-level inverter phase voltages with no fault condition is given in Figure 35 while distortion content with short fault is given in Figure 36. Figure 37 shows fault mitigated distortion content in phase voltage.

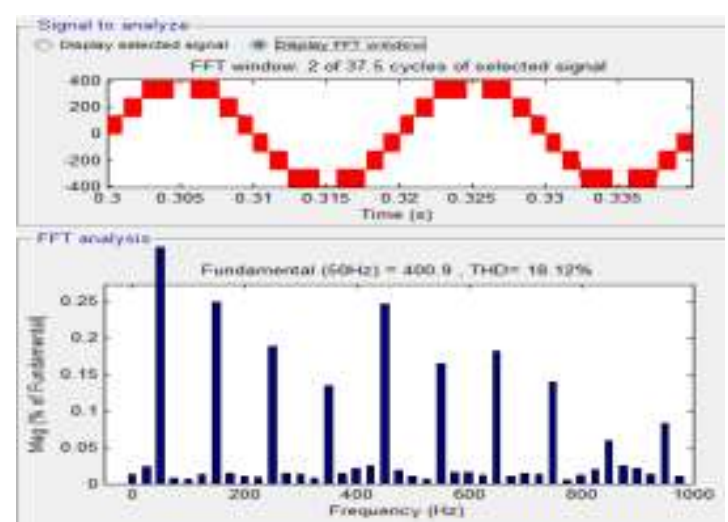

Figure 35. THD in phase voltage with switch short mitigation (before fault)

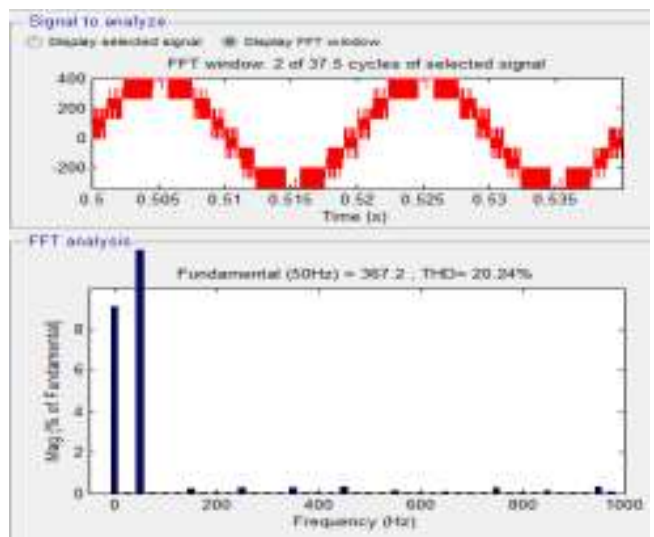

Figure 36. THD in phase voltage with switch short mitigation (after fault) 


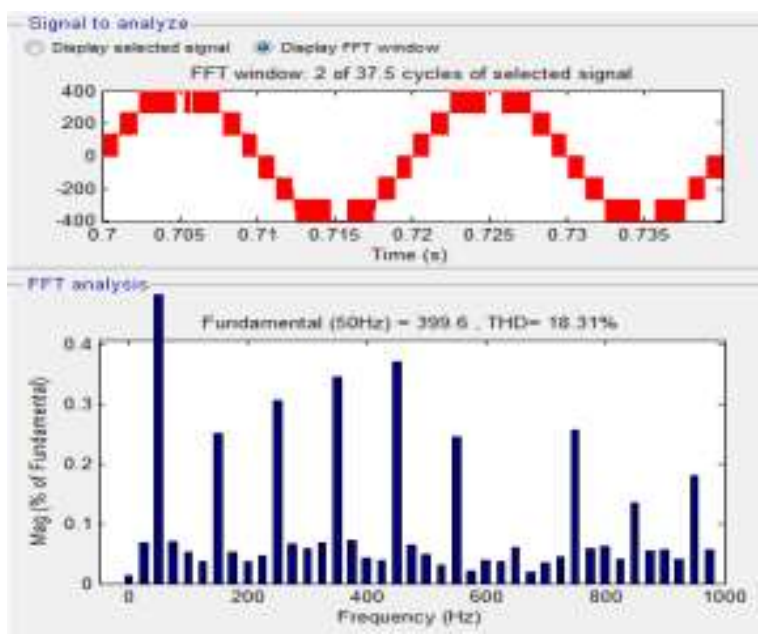

Figure 37. THD in phase voltage with switch short mitigation (after fault mitigation)

Figure 38 shows the line currents and Figure 39 shows the stator currents, speed and torque characteristics of induction motor for 7-level short fault mitigation.

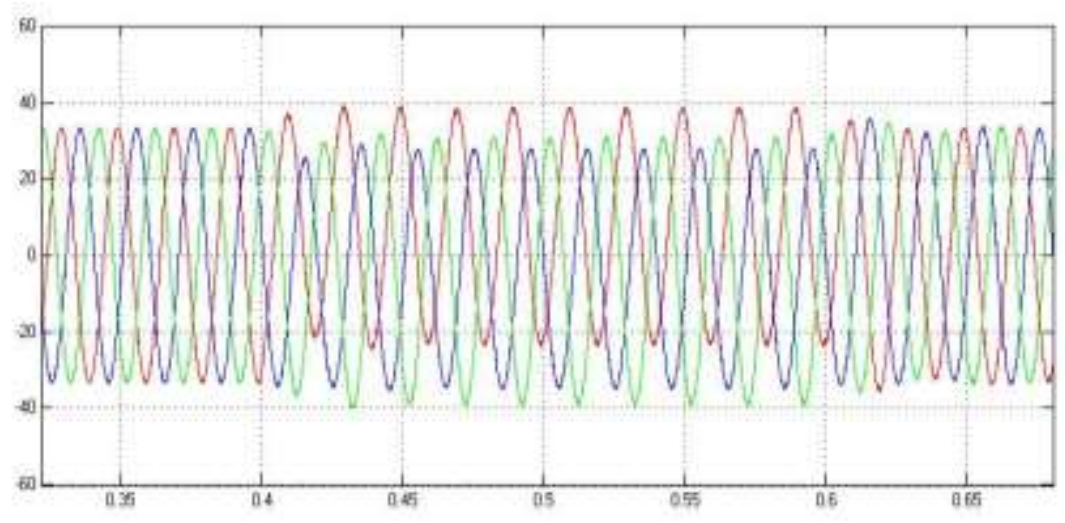

Figure 38. Line current with switch short mitigation
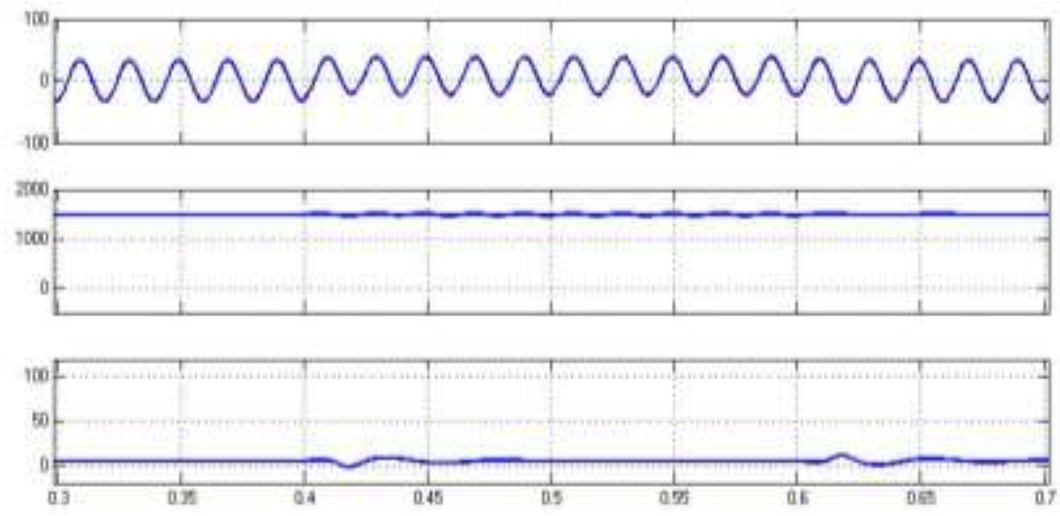

Figure 39. Stator current, speed and torque of induction motor with switch short mitigation

THD in stator current before fault was shown in Figure 40 while Figure 41 during the fault THD and Figure 42 THD after fault mitigation. 


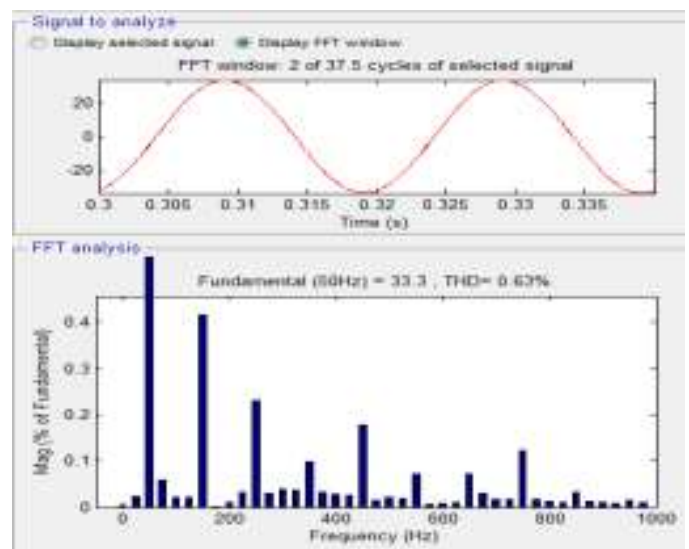

Figure 40. THD in stator current with switch short mitigation (before fault)

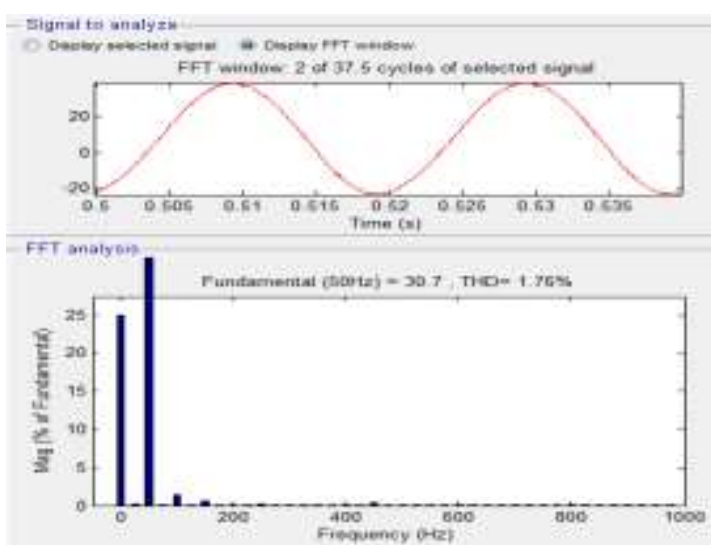

Figure 41. THD in stator current with switch short mitigation (during fault)

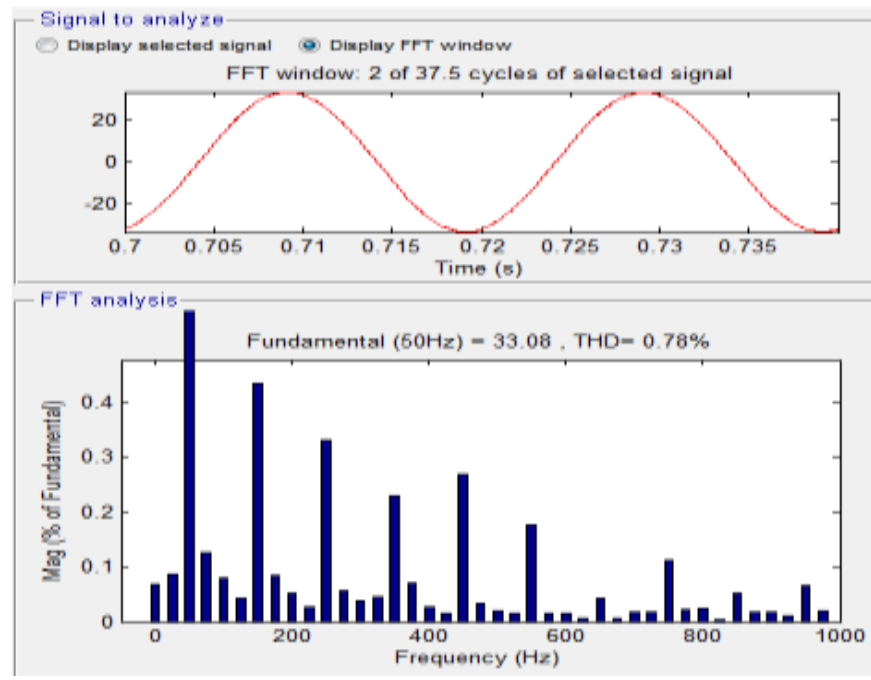

Figure 42. THD in stator current with switch short mitigation (after fault mitigation)

Table 1. THD in Phase Voltages

\begin{tabular}{ccccc}
\hline Level & Switch Condition & Before Fault & During Fault & After fault mitigation \\
\hline \multirow{2}{*}{ 5-Level } & Open & $26.04 \%$ & $36.49 \%$ & $25.5 \%$ \\
& Short & $26.04 \%$ & $28.77 \%$ & $25.5 \%$ \\
\multirow{2}{*}{ 7-Level } & Open & $18.12 \%$ & $24.97 \%$ & $18.31 \%$ \\
& Short & $18.12 \%$ & $20.24 \%$ & $18.31 \%$ \\
\hline
\end{tabular}

Table 2. THD in Stator Currents

\begin{tabular}{ccccc}
\hline Level & Switch Condition & Before Fault & During Fault & After fault mitigation \\
\hline \multirow{2}{*}{ 5-Level } & Open & $5.43 \%$ & $19.69 \%$ & $4.65 \%$ \\
& Short & $5.43 \%$ & $5.49 \%$ & $4.65 \%$ \\
\multirow{2}{*}{ 7-Level } & Open & $0.63 \%$ & $12.03 \%$ & $0.78 \%$ \\
& Short & $0.63 \%$ & $1.76 \%$ & $0.78 \%$ \\
\hline
\end{tabular}

\section{CONCLUSION}

In this paper redundant cell was used to mitigate the faults that occur in inverter which feed induction motors for electrical vehicles. Fault identification is essential to mitigate the faults. Redundant cell comes handy and operate when fault is present in the inverter circuit. This paper discusses the fault mitigation with redundant cell for seven level. The seven-level results were compared with five-level. THD in phase voltages and THD in stator current of induction motor are reduced as the level of output is increased. 
This was verified from the tabular column. The use of multilevel inverter and redundant cell can effectively reduce the fault and mitigates with reduction in THD in stator currents and phase voltages.

\section{REFERENCES}

[1] T. Singaravelu "Design and Implementation of Seven Level Cascaded H-Bridge Inverter Using Low frequency transformer with Single DC Source". T. Singaravelu et.al/International Journal of Engineering and Technology (IJET). Vol 5 No 3 Jun-Jul 2013, pp: 3068- 3076.

[2] M. Carraro and M. Zigliotto, "Automatic Parameter Identification of Inverter-Fed Induction Motors at Standstill," in IEEE Transactions on Industrial Electronics, vol. 61, no. 9, pp. 4605-4613, Sept. 2014.

[3] S. Priya, A. Suresh, M. R. Rashmi "GCMT-249 Investigation and Performance Analysis of Direct Torque Control of 3Ф Induction Motor using 7 Level Neutral Point Clamped Multilevel Inverter" IJST Volume 9, Issue 24, June 2016.

[4] K. K. Nallamekala and K. Sivakumar, "A Fault-Tolerant Dual Three-Level Inverter Configuration for Multipole Induction Motor Drive With Reduced Torque Ripple," in IEEE Transactions on Industrial Electronics, vol. 63, no. 3, pp. 1450-1457, March 2016.

[5] Porselvi, \& Muthu, R. Wind Energy Conversion System with Boost Converter and CHB MLI with single DC input. Porselvi $T$ et al./International Journal of Engineering and Technology (IJET). Vol 6 No 1 Feb-Mar 2014, pp: 138-145.

[6] P. Rajasekaran, V. Jawahar Senthilkumar "Comparative Analysis of Two Level VSI and Three Level Neutral Point Clamped Inverter for Torque Ripple Reduction in Induction Drive" IJST Volume 9, Issue 7, February 2016.

[7] Kumara Swamy, YP Obulesu, "Modified SVPWM Algorithm for 3-Level Inverter Fed DTC Induction Motor Drive," International Journal of Power Electronics and Drive Systems (IJPEDS), Vol 7, No 4: December 2016, pp $1134-1145$.

[8] Zakaria M. S. El-Barbary, H. Z. Azazi, M. K. Metwally, "Total Harmonic Distortion Analysis of a Four Switch 3Phase Inverter Fed Speed Sensorless Control of IM Drives," International Journal of Power Electronics and Drive Systems (IJPEDS), Vol 4, No 1: March 2014, pp 81-90.

[9] K. Satyanarayana, B. Anjaneyulu, K. Siva Prasad, "Performance Improvement of Multi Level Inverter fed Vector Controlled Induction Motor Drive for Low Speed Operations," International Journal of Power Electronics and Drive Systems (IJPEDS), Vol 4, No 1: March 2014, pp 51-60.

[10] K. M. Siddiqui, K. Sahay and V. K. Giri, "Early, diagnosis of bearing fault in the inverter driven induction motor by wavelet transform," 2016 International Conference on Circuit, Power and Computing Technologies (ICCPCT), Nagercoil, 2016, pp. 1-7.

[11] B. D. E. Cherif, M. Bendjebbar and A. Bendiabdellah, "Diagnosis of open-circuit fault in a three phase voltage inverter fed induction motor," 2015 4th International Conference on Electrical Engineering (ICEE), Boumerdes, 2015, pp. 1-4. 